\title{
GENOTOXICITY OF SOME COMMONLY USED ANTIDEPRESSANTS (FLUOXETINE, SERTRALINE AND CLOMIPRAMINE)
}

\author{
$\mathcal{B Y}$ \\ Eman I. Draz*, Ashraf M. Emara*, Khaled M. Saad*, Adel Badaway**, \\ Hassab El-Nabi S. E.*** and Heba Abd-Elgelil**** \\ Departments of Forensic Medicine and Clinical Toxicology *, Neuropsychiatric **, Zoology*** and Pharmacology**** \\ Faculty of medicine, Tanta University*, **, ****, Faculty of Science, Menofia University***, Egypt.
}

\begin{abstract}
Genotoxic drugs may not produce pronounced harmful effects early during the course of medication. Unfortunately these harmful effects may appear later. Identification of genotoxic antidepressants as a long term medications is important to avoid their prescription. In the present study, thirty eight patients were under treatment of antidepressants [Tricyclic antidepressant (TCA) and selective serotonin reuptake inhibitor (SSRIs)], were compared with ten (5 males and 5 females) untreated healthy volunteers matched with patients. All patients meeting "Structured Clinical Interview for Diagnostic and Statistical Manual of Mental Disorders (DSM-IV) criteria for both generalized anxiety disorder and major depression" and were treated at Neuropsychiatry department of Tanta university hospital . Fluoxetine treated pt were 7 males and 10 females, sertraline treated pt were 5 males and 5 females and clomipramine treated pt were 6 males and 5 females. Detection of total genomic damage in all subjects was performed by DNA gel electrophoresis. The intensity of peripheral leucocytes DNA damage were measured by measuring optical density of DNA fragments at 200bp and 400bp by software Gel Pro program as maximum optical density values. There was a significant increase in DNA damage in all treated groups compared with the control. Male showed significant increase in DNA damage in comparison with females. Fluoxetine caused the most drastic DNA damage whereas sertraline caused an intermediate effect and clomipramine was the least genotoxic of the three compounds.
\end{abstract}

\section{INTRODUCTION}

Antidepressants are drugs that relieve the symptoms of depression. They were first developed in the 1950s and have been used regularly since then. There are almost thirty different kinds of antidepressants available today and there are four main types include Tricyclics, Monoamine oxidase inhibitors (MAOIs), selective serotonin reuptake inhibitors (SSRIs), and serotonin and norepinephrine reuptake inhibitors (SNRIs) (Josephy, 2003). 
Tricyclic antidepressant (TCAS) were the first available antidepressants used in western medicine, becoming available in the mid-twentieth century. The first of these agents was amitriptyline. They blocks both serotonin and norepinephrine at presynaptic CNS nerve terminals, resulting in increase levels of both serotonin and norepinephrine in the synaptic cleft. The increased availability of neurotransmitter to the post synaptic neurotransmitter receptors is believed to account for the antidepressant activity of these agents. These agents also have multiple effects at other receptors, including antimuscarinic, $\alpha$-adrenergic receptor and cardiac tissue. TCAs are considered very dangerous in overdose with significant antimuscarinic activity, cardiac dysrhythmias, and seizures being the most problematic (Josephy, 2003).

Post hoc analyses based on the results of genotoxicity studies carried out using Drosophila melanogaster suggested that the increased risk could be attributed to the use of the six genotoxic tricyclic antidepressants namely, amoxapine, clomipramine, desipramine, doxepin, imipramine, trimipramine (Van Schaik and Graf, 1991 and 1993).

Physicians should consider genotoxicity data when prescribing medications and should avoid prescribing the genotoxic TCAs and should prescribe the non- genotoxic TCAs including amitriptyline, maprotiline, nortriptyline, and protriptyline. There is an immediate effect, but it's not detected until a decade later, or more. The drugs seem to damage DNA, which promotes the growth of cancerous tumors. In women taking the genotoxic drugs the risk of breast cancer was more than double. Those who took the non-genotoxic drugs did not have increased risk. The breast cancer did not show up until 11 to 15 years after initial prescription of the medication (Sharpe et al., 2002).

Clomipramine was used in the current study as a model for tricyclic antidepressant. Clomipramine (Anafranil) is presumed to influence obsessive and compulsive behaviors through its effects on serotonergic neuronal transmission. The actual neurochemical mechanism is unknown, but CMI's capacity to inhibit the reuptake of serotonin (5-HT) is thought to be important (Gokay et al., 2004).

Selective serotonin-reuptake inhibitors (SSRIs) are used in the treatment of various forms of psychiatric disorders including depression, obsessive-compulsive disorder, panic attacks, and social phobias. They are safer than and as effective as the other antidepressants. These agents selectively block the reuptake of serotonin in the presynapses. Their safety profiles in adults are considered preferable to other antidepressants, particularly in the treat- 
ment of depression among those with cardiovascular disease. Overdose and adverse effect profile of them differ from the TCAs in that the SSRIS have minimal antimuscarinic and cardiovascular effects (Berkman et. al., 2003). Preclinical studies in laboratory animals have indicated that SSRIs were not genotoxic, but clear results from in vitro testing of SSRIs in a human cell system are currently scarce. Sertraline would be considered first in the treatment of psychiatric disorders requiring SSRI therapy in the future. Unlike Fluoxetine, Sertraline has low potential for pharmacokinetic drug interactions. So, Sertraline would be considered first in the treatment of psychiatric disorders requiring SSRI therapy in the future. Fluoxetine represents the prototype of the SSRIs and has been in wide spread use for over a decade (Gokay et al., 2004). In the present study, sertraline (Zoloft) and fluoxetine (Prozac) were chosen as model of SSRIs as, they are the most common antidepressants used in psychiatric department, in Tanta University hospital.

Electrophoresis techniques used in the assessment of DNA damage include alkaline gel electrophoresis and pulsed field gel electrophoresis. The measurement and analysis are mostly done with specialized gel analysis software. DNA Gel electrophoresis is generally only used after amplification of DNA via PCR. Hassab El Nabi (2000) modified a simple method for
DNA isolation. This method does not require expensive and environmental hazardous reagent and equipment.

In the present study, peripheral leucocytes from sertraline, fluoxetine or clomipramine treated psychiatric patients were examined for DNA total genomic damage using the modified DNA gel electrophoresis to evaluate and compare genotoxicity of these medication with each other and a control group of non treated healthy persons.

\section{SUBJECTS AND METHODS}

The present study was conducted on forty eight subjects, ten were untreated healthy volunteers and thirty eight were treated patients meeting "Structured Clinical Interview for Diagnostic and Statistical Manual of Mental Disorders IV (DSM-IV( criteria for both generalized anxiety disorder and major depression" at Neuropsychiatry department of Tanta university hospital. The participants were selected on the basis of similar responses to a questionnaire assessing risk of genotoxicity related to other aspects of life, medical histories, biological and dietary factors. All subjects were non-smokers and their ages ranged from 22 to 46 years. All patients were under treatment with the most common antidepressant drugs used on Tanta University Hospital, namely sertraline (Zoloft), fluoxetine (Prozac), and clomipra- 
mine (Anafranil). Period of receiving medication was ranging from 10-20 months. All participants were from the same geographical area. They had no known history of exposure to psychopharmacological therapy and written consents were taken. Subjects were divided into 5 groups as follow:

1- Control group: consisted of 10 (5 male and 5 female) healthy untreated personnel.

2- Fluoxetine treated group: 17 (7 male and 10 female) patients were treated with fluoxetine as $20-60 \mathrm{mg} / \mathrm{d}$ daily dose.

3- Sertraline treated group: 10 (5 male and5 female) patients under sertraline medication as $50-100 \mathrm{mg}$ daily dose.

4- Clomipramine treated group: 10 (6 male and 5 female) patients were receiving clomipramine as $75-300 \mathrm{mg} /$ d daily dose.

Five $\mathrm{ml}$ of blood was taken from each subject at night on heparinized syringes and kept in the refrigerator.

\section{Leucocytes isolation :}

Erythrocytes were removed from blood by suspending cells in erythrocytes lysing solution (0.15M NH4CL. 1Mm $\mathrm{NaHCO}_{3}, 0.1 \mathrm{Mm}$ EDTA). Whole blood was incubated with $8 \mathrm{ml}$ erythrocyte lysing solution, centrifuged for $5 \mathrm{~min}$. at 1000 rpm. Centrifugation was repeated twice more till a white pellet appeared. The pellets were washed two times with culture medium (RPM1 1640 medium solution with L- glutamine, Sigma), Suspended with $10 \%$ fetal solution calf serum (sigma) and $0.1 \%$ penicillin $(5000 \mathrm{IU} / \mathrm{ml}$ ), streptomycin $(5000 \mathrm{mg} / \mathrm{ml}$ solution. The leucocytes were distributed in $15 \mathrm{ml}$ sterilized falcon tubes at appropriate concentration $\left(7 \times 10^{3}\right.$ cells $\left./ \mathrm{ml}\right)$ (Hasab El Nabi, 2004).

\section{Total genomic damage of DNA:}

Total genomic damage of DNA was detected according to Hasab El Nabi, 2000. From leucocytes, $2 \times 10^{3}$ cells were centrifuged, the pellets were suspended in 18 microlitre medium and loaded directly into the cell of agarose gel; 18 microlitre of lysing buffer (50 mM NaCl, $1 \mathrm{mM} \mathrm{Na}_{2}$ EDTA, 0.5\% SDS, pH 8.3) was added, also 5 microlitre from 6x loading buffer was added into the wells. After $30 \mathrm{~min}$ electrophoresis was performed for $1 \mathrm{~h}$ at 50 volt using $1 \mathrm{x}$ TBE buffer as running buffer. Gel was photographed using a Polaroid camera while the DNA was visualized using a 312 nm UV light under transluminator.

\section{Gel preparation :}

Gel was prepared using $1.8 \%$ electrophoretic grade agarose (BRL). The agarose was boiled with tris- borate EDTA buffer (1x TBE buffer, $89 \mathrm{Mm}$ tris, $89 \mathrm{Mm}$ boric acid, 2Mm EDTA, Ph 8.3), and then, 0.5 
microgram $/ \mathrm{ml}$ ethidium borate was added to agarose mixture at $40^{\circ} \mathrm{C}$. Gel was poured and allowed to solidify at room temperature for $1 \mathrm{~h}$ before samples were loaded (Hasab El Nabi, 2004).

\section{DNA damage analysis :}

DNA damage appeared and located at $200 \mathrm{bp}$ molecular weight distance and its multiples like 400, 600 and $800 \mathrm{bp}$. The intensity of DNA damage were measured by measuring optical density of DNA fragments at 200 and 400 bp by software Gel Pro program as maximum optical density values (Hassab El nabi, 2000).

\section{Statistical analysis :}

Comparison between the mean values of optical densities of the studied groups was performed by student $-t$ test using SPSS 13.0 for windows evaluation version software computer program.

\section{RESULTS}

\section{DNA total genomic damage :}

Necrosis is accompanied by random DNA Breakdown, with diffuse smear in agarose gels. Intensity of DNA damage was measured by measurement of maximal optical density of DNA fragment at 200 and $400 \mathrm{bp}$. Intact DNA appears with no smear like a band at the base. (Figure, 1). Mild, moderate and severe DNA damage appear as mild, moderate and large diffuse smear respectively and the measured maximum optical densities at 200 and $400 \mathrm{bp}$ were expressed by software electropherograms (figure 2,3,4). As the optical density increases, the DNA damage increase. Oligonucleosomal DNA fragments that produce the characteristic DNA ladder (figure, 5) are released when the $50 \mathrm{~kb}$ fragments are further degraded. Optical density was measured at $200 \mathrm{bp}$ and $400 \mathrm{bp}$

\section{DNA damage in leucocytes of pa- tients:}

The obtained results revealed that female and male patients administered fluoxetine induced observable release of fragments of DNA i.e. DNA damage (plate 1 a and $b$ ). The optical density values were significantly elevated in both male (81.13 \pm 9.53 and $83.22 \pm 14.39)$ and female patients $(69.12 \pm 13.84$ and $37.35 \pm 8.98)$ at $400 \mathrm{bp}$ and 200bp respectively when compared with controls (male $33.17 \pm 8.66$ and 20.44 \pm 5.56 female $36.06 \pm 10.93$ and $19.62 \pm$ 5.57 respectively). The optical density values of male patients were significantly elevated when compared with that of female patients at optical density 400bp and 200bp (Table1).

Sertraline induced significant elevation in release of fragments of DNA in male group at $400 \mathrm{bp}(69.12 \pm 13.84)$ and female group $(37.56 \pm 6.92)$ at optical density $200 \mathrm{bp}$ when compared with controls (33.17 \pm 8.66 and $19.62 \pm 5.57$ respectively). 
The optical density values of release of fragments of DNA in male patients were significantly elevated when compared with that of female patients at optical density 400 and 200bp (Table1).

The obtained results revealed that female and male patients administered clomipramine induced mild release of fragments of DNA. The optical density values showed no significant elevation in release of fragments of DNA in both male and female groups at optical density $200 \mathrm{bp}$ and $400 \mathrm{bp}$ when compared with controls. . The optical density values of release of fragments of DNA in male patients were not significantly changed when compared with that of female patients at optical density 400 and 200bp (Table 1).

The study demonstrated that TCAs had pronounced DNA damage in human leucocytes, but to varying degrees. Distinct differences between the effects of fluoxetine, sertraline and clomipramine on human leucocytes were observed: Fluoxetine caused the most drastic DNA damage while sertraline produced the intermediate and clomipramine caused the least effect.

\section{DISCUSSION}

Traditionally, genetox data have been viewed as binary input, with results either "yes, genotoxic" or "no, not genotoxic," Typically, dose-response information is not considered in the interpretation of genetox data (Lynn et al., 2007).

DNA damage is a relatively common event in the life of a cell and may lead to mutation, cancer, and cellular or organismic death. DNA damage induces several cellular responses that enable the cell either to eliminate or cope with the damage or to activate a programmed cell death process, presumably to eliminate cells with potentially catastrophic mutations (Sancar et al., 2004).

Recently, several studies found that different members of TCAs can induce free radicals and oxidative stress in vitro (Post et al., 2000; Viola et al., 2000). DNA damage caused by oxygen-derived species including free radicals is the most frequent type encountered by aerobic cells and (marcus et al., 2003).

The current study demonstrated that the investigated antidepressants exerted pronounced DNA damage in human leucocytes, but to varying degrees. Distinct differences between the effects of fluoxetine, sertraline and clomipramine on human leucocytes were observed: fluoxetine caused the most drastic DNA damage and clomipramine the least. 
Supporting the present study, a study on assessment of DNA damage in C6 glioma cells after antidepressant (amitriptyline, imipramine (both tricyclics), fluoxetine (a selective serotonin re-uptake inhibitor) and tranylcypromine (a monoamine oxidase inhibitor) treatment using an alkaline comet assay conclude that there were increases in DNA damage with increasing concentrations of antidepressants. 3-isobutyl-1-methylxanthine (IBMX) pretreatment protected against antidepressant-induced DNA damage in C6 cells pretreated with dibutyryl cyclic AMP $(\mathrm{dBc} A M P)$ and. Addition of exogenous reduced GSH and L-buthionine sulfoximine (BSO) increased DNA damage after fluoxetine exposure. The data show that the antidepressants induce significant amounts DNA damage in C6 cells (Slamon et al., 2001).

Xia et al. (1996) found that, clomipramine could induce apoptosis in lymphocytes. Clomipramine has non-toxic cancer therapeutic effect with a strong selectivity between cancer cells and normal cells (Daley et al., 2005).

On the other hand, Brambilla et al. (2009) demonstrated that, Fluoxetine gave negative responses in all genotoxicity assays and were not carcinogenic, Clomipramine gave positive result(s) in genotoxicity assays but tested negative in carcinogenicity assays (which support the present study); and Sertraline tested negative in genotoxicity assays but were carcinogenic in rodents.

There is epidemiological evidence that antidepressant (whether tricylic antidepressants (TCA) or selective serotonin reuptake inhibitors (SSRI)) medication use may be associated with an increased risk of breast cancer in women (Wallace et al., 1982; Halbreich et al., 1996; Kelly et al., 1999; Cotterchio et al., 2000; Sharpe et al., 2002), although findings have been inconsistent, with three studies reporting no association (Friedman and Ury, 1983; Selby et al., 1989; Wang et al., 2001). The preponderance of animal studies also indicates that certain antidepressants may promote tumours in experimental models (Tucker, 1983; Bendele et al., 1992; Brandes et al., 1992; Hilakivi-Clarke and Lippman, 1993; Iishi et al., 1993; Steingart and Cotterchio, 1995). The widespread use of antidepressants (Rosholm et al., 1997; Ohayon et al., 1998; Hume et al., 1995) and the rise in incidence of breast cancer (Feuer et al., 1993; Madigan et al., 1995) have focused interest on whether antidepressants use, a potentially modifiable factor, may be associated with breast cancer risk.

Whereas Justin et al. (2008) conclude that, no significant associations between any class of antidepressant and any type 
of cancer in AIDs patients in either the pre HAART (highly active antiretroviral therapy) or HAART era and use of serotonin reuptake inhibitors did not alter the risk of Burkitt lymphoma.

Data from a study conducted by Patricia et al. (2005) provide some assurance that the use of SSRIs does not increase the risk of breast cancer.

\section{Conclusion and recommendation:}

The present study concluded that fluoxetine, sertraline and clomipramine may induce DNA damage with fluoxetine produced the most, sertraline produced the intermediate and clomipramine produced the least damage. Further studies should be performed on genotoxicity of antidepressants on larger number of patients with longer periods of treatment. 
Draz et al ...

Table (1): Statistical analysis of the opital densities of the studied groups.

\begin{tabular}{|c|c|c|c|c|c|c|}
\hline \multicolumn{2}{|c|}{ Groups } & \multirow{2}{*}{$\begin{array}{c}\text { Number of } \\
\text { patients } \\
5\end{array}$} & \multirow{2}{*}{$\begin{array}{c}\text { 400bp } \\
\text { (Mean } \pm \text { SD) } \\
33.17 \pm 8.66\end{array}$} & \multirow{2}{*}{$\begin{array}{c}\text { Student } \\
\text { test }\end{array}$} & \multirow{2}{*}{$\begin{array}{c}\text { 200bp } \\
(\text { Mean } \pm \text { SD) } \\
20.44 \pm 5.56\end{array}$} & \multirow{2}{*}{$\begin{array}{c}\text { Student } \\
\text { test }\end{array}$} \\
\hline Control & Male & & & & & \\
\hline & Female & 5 & $36.06 \pm 10.93$ & & $19.62 \pm 5.57$ & \\
\hline \multirow[t]{2}{*}{ Fluoxetine } & Male & 7 & $81.13 \pm 9.53^{*}$ & 13.230 & $83.22 \pm 14.39^{*}$ & 11.517 \\
\hline & Female & 10 & $69.12 \pm 13.84^{*}$ & 3.173 & $37.35 \pm 8.98^{*}$ & 4.426 \\
\hline \multirow[t]{2}{*}{ Sertraline } & Male & 5 & $43.97 \pm 9.85^{*}$ & 5.725 & $32.31 \pm 9.00$ & 2.134 \\
\hline & Female & 5 & $38.66 \pm 10.27$ & 0.353 & $37.56 \pm 6.92 *$ & 3.907 \\
\hline \multirow[t]{2}{*}{ Clomipramine } & Male & 6 & $23.86 \pm 3.10$ & 1.128 & $22.09 \pm 6.43$ & 0.349 \\
\hline & Female & 5 & $27.07 \pm 4.94$ & 1.411 & $17.93 \pm 3.40$ & 0.612 \\
\hline
\end{tabular}




\section{Fgure1}
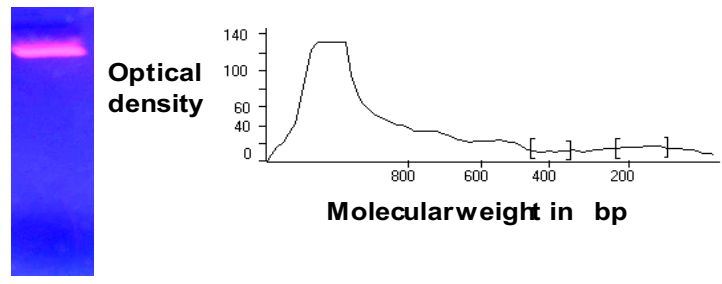

\section{Intad DNA}

\section{Figure 3}

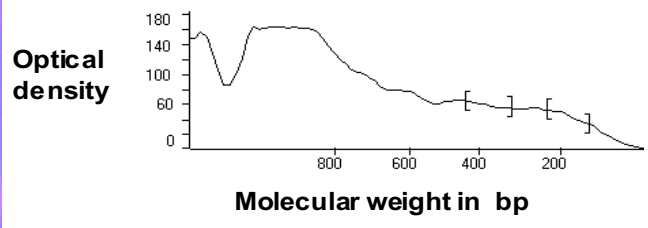

\section{Modera e DNAdamage}

Fgure2
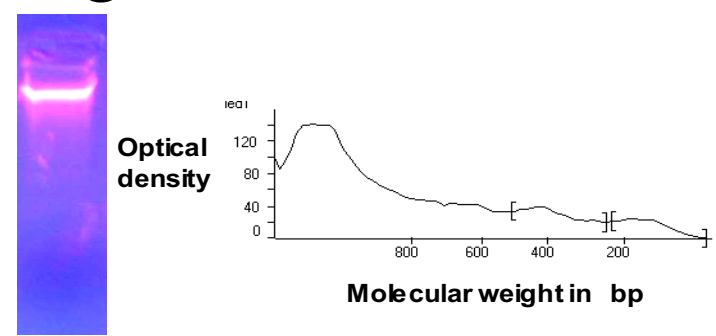

Mild DNA Damage

Figure4

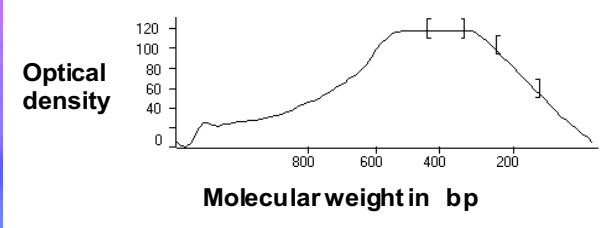

Severe DNADamage

Figure 5:

Ladder lane 


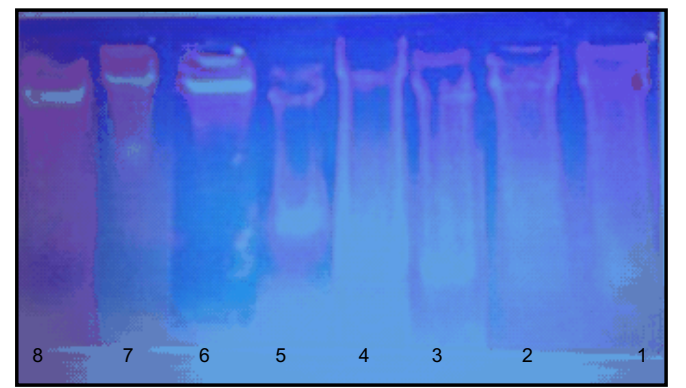

Plate 1a : An electrophoretic pattern of DNA damage in peripheral leucocytes of fluoxetine treated male patients (Lane 1-7) in comparison with the control (lane 8).

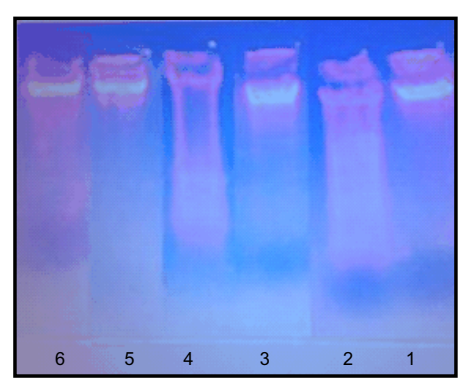

Plate 2a : An electrophoretic pattern of DNA damage in peripheral leucocytes of sertraline treated male patients (Lane 1-5) in comparison with the control (lane 6).

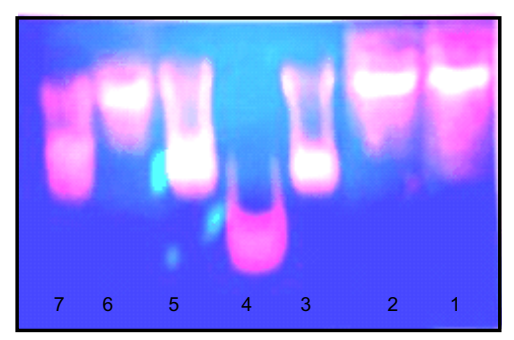

Plate 3a : An electrophoretic pattern of DNA damage in peripheral leucocytes of clomipramine treated male patient (Lane 27 ) in comparison with the control (lane 1).

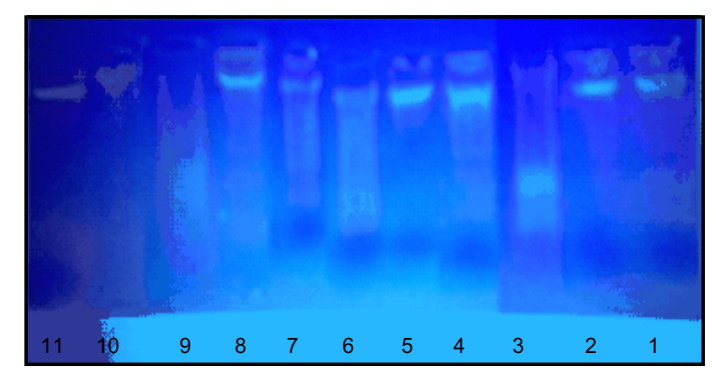

Plate 1b : An electrophoretic pattern of DNA damage in peripheral leucocytes of fluoxetine treated female patients (Lane 1-10) in comparison with the control (lane 11).

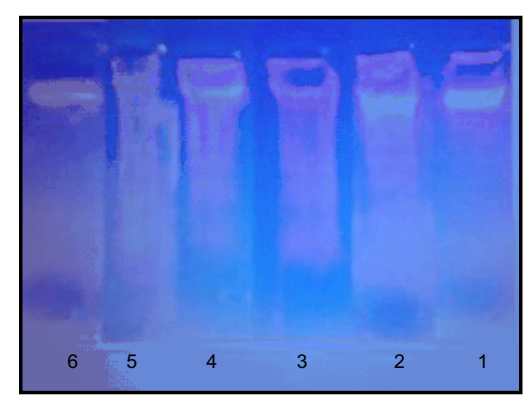

Plate 2b : An electrophoretic pattern of DNA damage in peripheral leucocytes of sertraline treated female patients (Lane 1-5) in comparison with the control (lane 6).

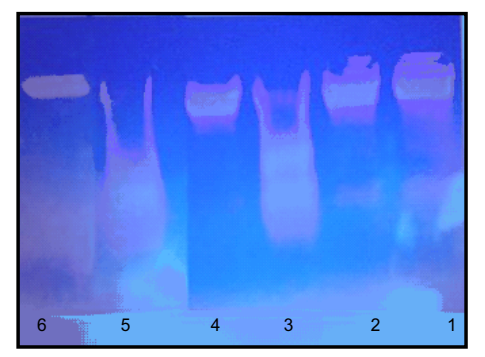

Plate 3b : An electrophoretic pattern of DNA damage in peripheral leucocytes of clomipramine treated female patients (Lane 1-5) in comparison with the control (lane 6). 


\section{REFERENCES}

Bendele, R. A.; Adams, E. R.; Hoffman, W. P.; Gries, C. L. and Morton, D. M. (1992) : "Carcinogenicity studies of fluoxetine hydrochloride in rats and mice". Cancer Res., 52:6931-6935.

Berkman, L. F.; Blumenthal, J.; Burg, M.; Carnew, R. M.; Catellier, D.; Cowan, M. J.; et. al. (2003) : “Effects of treating depression and low perceived social support on clinical events after myocardia infarction: the enhancing recovery in coronary heart disease patients (ENRICHD) randomized trial". Journal of The American Medical Association, 289 : 3106-3116.

Brambilla, G.; Mattioli, F. and Martelli, A. (2009) : "Genotoxic and carcinogenic effects of antipsychotics and antidepressants". Toxicology, 261: 77-88.

Brandes, L. J.; Arron, R. J.; Bogdanovic, R. P.; et al. (1992) : "Stimulation of malignant growth in rodents by antidepressant drugs at clinically relevant doses", Cancer Res., 52:3796-3800.

Cotterchio, M.; Kreiger, N.; Darlington, G. and Steingart, A. (2000) : "Antidepressant medication use and breast cancer risk". Am. J. Epidemiol., 151:951-957.

Daley, E.; Wilkie, D.; Loesch, A.; Hargreaves, I. P.; Kendall, D. A.; Pilkington,
G. J. and Bates, T. E. (2005) : “Chlorimipramine: a novel anticancer agent with a mitochondrial target". Biochem. Biophys. Res. Commun., Mar 11, 328(2):623-632.

Feuer, E. J.; Wun, L. M.; Boring, C. C.; Flanders, W. D.; Timmel, M. J. and Tong, T. (1993) : "The lifetime risk of developing breast cancer". J. Natl. Cancer Inst., 85 : 892-897.

Friedman, G. D. and Ury, H. K. (1983) : "Screening for possible drug carcinogenicity: second report of findings". J Nat. Cancer Inst., 71:1165-1175.

Gokay, B.; Ercan, A.; Ibrahim, A.; Goksel, K.; Mevlut, T.; Fatma, O. S.; Sukru P.; Kubra T. and Cetin, A. (2004) : "Clastogenicity of selective serotoninreuptake inhibitors mutation research". Genetic Toxicology and Environmental Mutagenesis, 558, (1-2) 14:137-144.

Halbreich, U.; Shen, J. and Panaro, V. (1996) : "Are chronic psychiatric patients at increased risk for developing breast cancer?". Am. J. Psychiatry, 153:559-560.

Hassab El-Nabi, S. E. (2004) : "Molecular studies on the relationship between apoptosis and DNA Damage induced by Dexamethasone and flumox in liver and spleen of rat and human lymphocytes culture". J. Egpyt. Ger. Soc. Zool, 54 : 175202. 
Hassab El-Nabi, S. E. (2000) : "Rapid and simple technique for detection of total genomic damage (TGD) of DNA in human lymphocytes and its application on some mutagenic agents". J. Union Arab Biol., 14(A): 371-388.

Hilakivi-Clarke, L. W. A. and Lippman, M. E. (1993) : "Neonatal antidepressant treatment promotes DMBA-induced mammary tumor growth". Proc. Am. Assoc. Cancer Res., 34:184.

Hume, A. L.; Barbour, M. M.; Lapane, K. L. and Carleton, R. A. (1995) : "Is antidepressant use changing? Prevalence and clinical correlates in two New England communities". Pharmacotherapy, 15:7884.

Iishi, H.; Tatsuta, M.; Baba, M. and Taniguchi, H. (1993) : "Enhancement by the tricyclic antidepressant, desipramine, of experimental carcinogenesis in rat colon induced by azoxymethane". Carcinogenesis, 14:1837-1840.

Josephy, A. L. (2003) : "History of the use of antidepressants in primary care, primary care companion". J. clin. Pysychiatry, 5(suppl 7):6-10.

Justin, S.; Tom, P.; Sundhiya, M.; Mark, N.; Brian, G. and Mark, B. (2008): Use of Antidepressants and Risk of Cancer in Individuals Infected With HIV. Journal of Clinical Oncology, 26, (14) P.P. 23052310 .

Kelly, J. P.; Rosenberg, L.; Palmer; J. R. et al. (1999) : "Risk of breast cancer according to use of antidepressants, phenothiazines, and antihistamines". Am. J. Epidemiol., 150:861-68.

Lynn, H.; Pottenger, L; James, S. and Bus, B. (2007): “Bhaskar Gollapudi Genetic Toxicity Assessment: Employing the Best Science for Human Safety Evaluation Part VI: When Salt and Sugar and Vegetables Are Positive, How Can Genotoxicity Data Serve to Inform Risk Assessment?". Toxicological Sciences, 98(2):327-331.

Madigan, M. P.; Ziegler, R. G.; Benichou, J. and Byrne, C. (1995) : "Proportion of breast cancer cases in the United States explained by well-established risk factors". J. Nat. Cancer Inst., 87:1681-1685.

Marcus, S. C.; mark, D. E.; Miral, D. and Joseph, 1. (2003) : "Oxidative DNA damage: mechanisms, mutation, and disease". FASEB Journal, 17:1195-1214.

Ohayon, M. M.; Caulet, M.; Priest, R. G. and Guilleminault, C. (1998) : "Psychotropic medication consumption patterns in the UK general population". J. Clin. Epidemiol, 51:273-283.

Patricia, F.; Coogan, J. R. Palmer, Brian 
L.; Strom and Lynn Rosenberg (2005) : "Use of selective serotonin reuptake inhibitors and the risk of breast cancer. American Journal of Epidemiology, 162(9):835838.

Post, A.; Crochemore, C.; Uhr, M.; Holsboer, F. and Behl, C., (2000) : “Differential induction of NF-kappaB activity and neural cell death by antidepressant in vitro". Eur. J. Neurosci., 12 (12): 4331-4337.

Rosholm J. U.; Gram, L. F.; Isacsson, G.; Hallas, J. and Bergman, U. (1997) : "Changes in the pattern of antidepressant use upon the introduction of the new antidepressants : a prescription database study". Eur J. Clin. Pharmacol., 52 : 205-209.

Sancar, A.; Lindsey-Boltz; L. A.; Unsal-Kaçmaz, K. and Linn, S. (2004) : “Molecular mechanisms of mammalian DNA repair and the DNA damage checkpoints. Annu. Rev. Biochem., 73: 39-85.

Selby, J. V.; Friedman, G., D. and Fireman, B. H. (1989) : “Screening prescription drugs for possible carcinogenicity : eleven to fifteen years of follow-up". Cancer Res., 49:5736-5747.

Sharpe, C. R.; Collet, J. P.; Belzile, E.; Hanley, J. A. and Boivin, J. F. (2002) : "The effects of tricyclic antidepressants on breast cancer risk". Br. J. Cancer, 86:92-97.
Slamon, N. D.; Ward, T. H.; Butler, J. and Pentreath, V. W. (2001) : "Assessment of DNA damage in C6 glioma cells after antidepressant treatment using an alkaline comet assay". Arch. Toxicol., 75 (4) : 243250.

Steingart, A. B. and Cotterchio, M. (1995) : "Do antidepressants cause, promote, or inhibit cancers? J. Clin. Epidemiol., 48:1407-1412.

Tucker, W. E. (1983) : "Preclinical toxicology of bupropion: an overview". J. Clin. Psychiatry, 44:60-62.

Van Schaik, N. and Graf, U. (1991) : "Genotoxicity evaluation of five antidepressants in the wing somatic mutation and recombination test in Drosophila melanogaster". Mutat. Res., 260:99-104.

Van Schaik, N. and Graf, U. (1993) : "Structure-activity relationships of tricyclic antidepressants and related compounds in the wing somatic mutation and recombination test of Drosophila melanogaster". Mutat. Res., 28:6-163.

Viola, G.; Miolo, G.; Vedaldi, D. and Dall'acqua, F. (2000): "In vitro studies of the phototoxic potential of the antidepressant drugs amitriptyline and imipramine". Farmaco., 55 (3): 211218. 
Wallace, R. B.; Sherman, B. M. and of breast cancer: a non-association". J. Bean, J. A. (1982) : "A case-control study of breast cancer and psychotropic drug use. Oncol., 39:279-283. Clin. Epidemiol., 54:728-734.

Xia, Z.; DePierre, J. W. and Nassberger, L. (1996) : "The tricyclic antidepressants Wang, P. S.; Walker, A. M.; Tsuang, M. clomipramine and citalopram induce T.; Orav, E., J.; Levin, R. and Avorn, J. apoptosis in cultured -human lympho(2001) : "Antidepressant use and the risk cytes". J. Pharm. Pharmacol., 48, 115-116. 


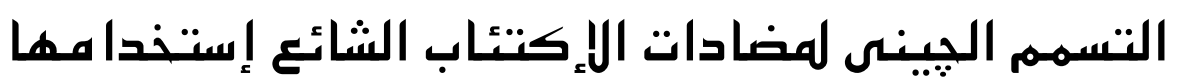 (فلو كسيتين، سرترالين، وكلو عيبرا عبين)
}

\author{
المثتركون فى البحث
}
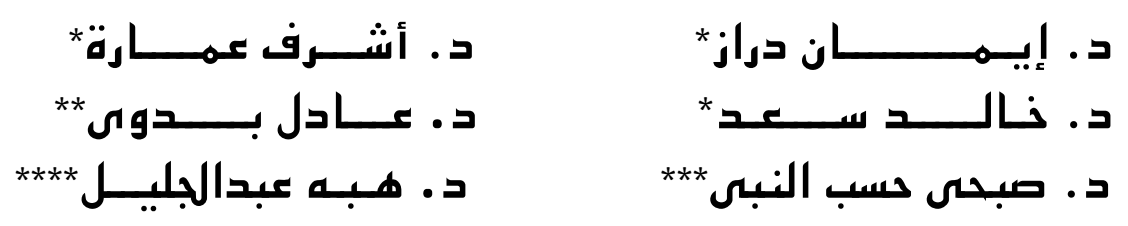

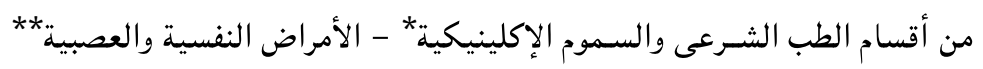

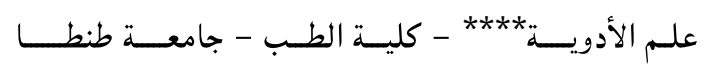

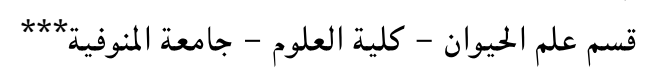

قد لاتعلن الأدوية السامة جِينياً عن تأثيراتها الضارة فى بداية العلاج ولكن لسوء الحظ تظهر هذه التأثيرات الضارة بعد فترة طويلة من الاستخدام، التعرف على مضادات الإكتئاب السامة جينياً هو أمر هام وذلك لتجنب وصفها للعلاج، فى هذه الدراسة تم مقارنة ثمانية وثلاثين مريض يتم علاجهم بمضادات إكتئاب شائع إستخدامها (ثلاثية الحلقة والمنتقاة لمنع إعادة أخذ السيروتينين) . عشرة أشخاص مجموعة ضابطة (0) رجال و ه نساء) أصحاء يتكافئون مع المرضى، يتفق جميع المرضى مع المقابلة الإكلينيكية المنظمة لمواصفات الكتيب التشخيصى والعلاجى للإضطرابات العقلية فيما يتعلق بالقلق العام والاكتئاب الشديد. وقد كان عدد المرضى المعالجين بالفلوكسيتين V ذكور و . ا إناث والسرترالين ه ذكور وه إناث وكلوميبرامين 1 ذكور و ه إناث، وتلقى جميع المرضى العلاج فى فترة تراوحت مابين ـ ا- . ب شهر ، وتم عمل الكشف عن التلف الجينى العام الحادث فى كرات الدم البيضاء السطحية فى جميع الأشخاص باستخدام جهاز الهجرة الكهربائية لحمض إل د إن أى فى

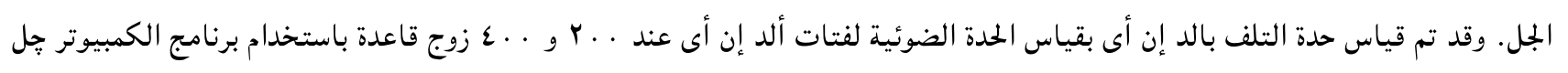

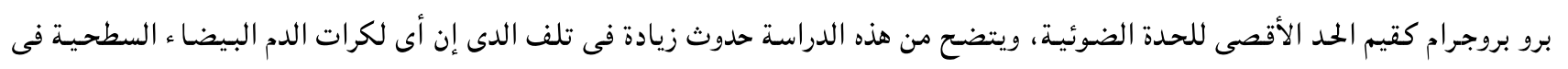
المجموعة الحخاضعة للعلاج (التى لوحظ فيها زيادة فى تلف الدى إن أى فى الإناث بالمقارنة بالذكور) بالمقارنة بالمجموعة الضابطة بدرجات متفاوتة، فقد كان الفلوكسيتين أكثرهم تلفاً للدى إن أى والسر تر الين سبب تأثيراً متوسطاً وأما كلوميبرامين فقد كان أقلهم تأثيراً. 